of predictive thinking with a focus on the quality results prediction. The novelty of the study is the developing an algorithm for the implementation of the reflexive-design paradigm of education and determination of its basic provisions as acme-guides for the development of young people of generation Z.

Key words: generations theory, socio-psychological features of young generation Z, algorithm of realization of the reflexive-design paradigm of education, basic positions.

Дата надходження статті: 30.10.2020 p.

Рецензент: доктор педагогічних наук, доцент Примакова В.В.

\author{
У,К 372.2/.3.015.31:070](477) \\ DOI https://doi.org/10.37915/pa.vi46.105
}

Кузьма I. I.,

orcid.org/0000-0002-1219-8216

\title{
ФОРМУВАННЯ МОТИВАЦІЇ ДО МЕДІАОСВІТИ В ДІТЕЙ СТАРШОГО ДОШКІЛЬНОГО ТА МОЯОДШОГО ШКІЛЬНОГО ВІКУ
}

У статті обьрунтовано форми й методи формування мотивації до медіаосвіти в дітей старшого дошкільного та молодшого шкільного віку в контексті наступності. Запропоновано використання нового медіапродукту - медіаосвітньої казки на теми визначення понять, пошуку інформацїі, диференціації правди й неправди в медіа, дотримання авторського права, економічних, праксеологічних аспектів медіа, їхнього безпечного використання.

Зазначено, що медіаосвіта - актуальна міждисииплінарна проблема, численними є напрями медіаосвіти. Для їхнвої реалізациї необхідні нові підходи, передусім формування мотивації в дітей дошкільного та молодиого шкільного віку в контексті наступності. Корисність, привабливість (видовищність, радісність), ціікавість визначено як мотиви, що спонукають до занять у сфері медіаосвіти.

Акцентуеться увага на негативному впливі надмірного використання новітніх медіа. Зазначено, що в початкових школах на формування медіаграмотності учнів спрямовані типові освітні програми. Водночас ия робота потребуе посилення в закладах дошкільної освіти.

Виявлено необхідність створювати мотиваццію для медіаосвіти та ї реалізувати у співпраці педагогічних працівників, батьків, дітей (бесіди, розповіді, ігри, вправи, проєкти, тренінги про значення навчання про медіа, через медіа, для медіа); за допомогою поєднання медіаосвіти з різними напрямами виховання: моральним, естетичним, трудовим та ін., що відображено в медіаосвітніх казках. Визначено перспективні форми роботи - написання сценнаріїв мінівистав із участю популярного герол мультиплікаціийних фільмів Тітоньки Сови; медіаосвітнього свята «Медіа єднає друзів» тощо.

Акцентовано увагу, що розроблені форми й методи формування мотивації до медіаосвіти є джерелом для вияву творчості педагогічних колективів початкових шкіл, батьків та дітей, подальщих наукових розвідок.

Ключові слова: заклад дошкільної освіти, заклад початкової освіти, медіа, медіаосвіта, медіаграмотність, мотивація до медіаосвіти, медіаосвітня казка, форми, методи медіаосвіти.

Постановка проблеми. Серед освітніх проблем чи не найбільше уваги прикуто до медіаосвіти: впродовж останнього десятиріччя затверджено дві Концепції щодо ії впровадження, започатковано декілька експериментальних програм, метою яких є формування медіаграмотності дітей та мододі, постійно підтримується інтерес до зарубіжних досліджень та наукових здобутків вітчизняних учених. Незважаючи на це,

*C) Кузима I. I.

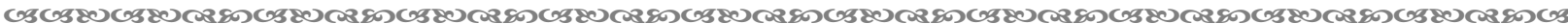


вчені зауважують, що е ще багато питань, відповіді на які однозначно не сформульовані. I це не дивно, адже медіаосвіта - актуальна міждисциплінарна проблема, що перебуває у сфері розвідок таких наук, як теорія літератури, журналістика, політологія, педагогіка, психологія, соціодогія, антропологія, історія мистецтва, естетика тощо. Численними є напрями медіаосвіти. Це й ознайомлення з елементарними медіапоняттями, уміння пошуку інформації, диференціація правдивих i неправдивих повідомлень, стимулювання безпечної поведінки, вивчення особливостей медіапродукції (культурне

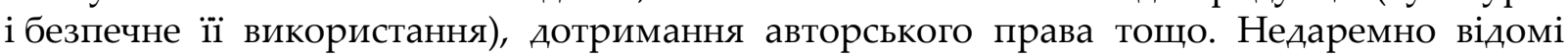
американські вчені С. Шейбе та Ф. Рогоу порівнюють медіаграмотність із тканиною 3 багатьма перехресними смугами різної ширини та кольорів, що деколи перекриваються, затемнюють одна одну, змішуються або існують у додаткових, але паралельних світах [5, с. 61].

Серед напрямів медіаосвіти є вкрай привабливі для дітей, наприклад знайомство 3 цифровими медіа та їхне використання передусім для розваги й комунікації, а також такі, які становлять труднощі: дотримання правил безпечного застосування новітніх медіа (обмежений час взаємодії з гаджетами, виявлення недостовірної інформації), відмова від віртуальних ігор, дотримання авторського права та ін. А отже, педагогічний працівник повинен створити мотивацію до медіаосвіти в різноманітності її напрямів.

Аналіз досліджень. Проблеми формування медіаграмотності дітей дошкільного та молодшого шкільного віку студіюють вчені Н. Ашиток, Е. Бжищ, Н. Гавриш, О. Качура, Р. Кондратенко, О. Кравчишина, К. Крутій, О. Олійник, О. Полєвикова, Ю. Семеняко, О. Соцька, Т. Чашка тощо; учнів у школі першого ступеня - Т. Бакка, Г. Дегтярьова, I. Іванова, 3. Збуг, $\quad$ С. Крамаровська, О. Шкребець, О. Янкович, Й. Ящищук-Рогалдо та ін. Науковці виокремили напрями, форми, методи, розробили засоби медіаосвіти, виявиди позитивні й негативні функції медіазасобів у закладах дошкільної та початкової освіти.

Польська вчена А. Огоновська, усебічно розглянувши проблеми медіаосвіти впродовж життя, основними принципами якої є навчання про медіа, через медіа і для медіа, визначила труднощі в іiі впровадженні: динамічний розвиток медіа, медіакультури і явищ, що ії супроводжують; складність охоплення в освітньому процесі різноманітних напрямів медіаосвіти, реалізація освітніх та терапевтичних цілей медіа [10, с. 180].

На досягненні дітьми життєвих цілей із використанням медіа акцентується увага в наукових розвідках І. Кузьми, Г. Терещука, Г. Фальфушинської, О. Янкович. Розробивши модель технології формування успішної особистості учня молодшого шкільного віку засобами медіаосвіти, автори вказали на необхідність взаємозв'язку педагогіки успіху та серця і тим самим розвинули напрям морально-етичних аспектів медіа [11, с. 154]. Науковці зазначають: «Доцільно вирішувати проблеми досягнення успіху водночас із підвищенням рівня медіакультури учнів у партнерстві з батьками й учителями» [там само, с. 145]. Так само медіаосвіту необхідно поєднувати 3 різними напрямами виховання, зокрема з моральним вихованням, на що вказуе О. Янкович [6].

Заслуговуе на увагу дослідження Ю. Семеняко щодо виховання в дітей старшого дошкільного віку основ культури використання медіапродукції в закладах дошкільної освіти. У структурі вихованості дошкільника науковець виокремила емоційно-ціннісний компонент. Вона, зокрема, зазначає: «Зважаючи на ціль, яку передбачає досягти дитина в результаті використання медіапродукції, можна розгдядати такі мотиви: пізнавальний (розширення знань, задоволення пізнавального інтересу); комунікативний (задоволення потреби в спілкуванні); релаксаційний (отримання позитивних емоцій) і компенсаторний (заміщення будь-яких переживань)» [2, с. 101].

Висвітливши не тільки здобутки під час реалізації медіаосвіти, а й труднощі, які виникають у процесі здійснення такої діяльності, учені недостатньо дослідили проблему формування мотивації до медіаосвіти в дітей дошкільного та молодшого шкільного віку بs 
в контексті наступності. Водночас визначення нових шляхів створення мотивації дадо б змогу охопити якомога більше напрямів медіаосвіти в закладах дошкільної та початкової освіти, залучивши батьків до цієї поліаспектної роботи.

Мета статті: обгрунтувати форми й методи формування мотивації до медіаосвіти дітей старшого дошкільного та мододшого шкільного віку в контексті наступності.

Виклад основного матеріалу. Наслідуючи приклад американських учених С. Шейбе та Ф. Рогоу, які порівнюють медіаграмотність (результат медіаосвіти) 3 тканиною з різноманітних волокон, медіаосвіту уявляємо як усебічну життедіяльність у будинку, де відбуваються навчання, відпочинок, оздоровлення, спілкування, прибирання тощо, і все це 3 дотриманням правил техніки безпеки. Якщо їх порушити, то оселя може зруйнуватися. У будинку ми виконуємо діяльність, що приносить нам задоволення: відзначення свят, перегляд улюблених програм, комунікація з родиною та друзями; а також ту, яка є необхідною, складною і не завжди приємною: ремонтні роботи, прибирання. Так само й медіаосвіта: вона багатоаспектна, кожен напрям є важдивим; ігнорування котрогось із них може не дати змоги досягти бажаного результату.

Таке порівняння 3 підтриманням життедіяльності в будинку особливо актуальне, коли формується мотивація до медіаосвіти. Серед іï напрямів є цікаві й бажані для дітей та дорослих, а є необхідні і не завжди привабливі. Це стосується передусім дотримання вимог безпечного використання новітніх медіа.

Сучасне покодіння називають дітьми мереж, адже відповідно до резудьтатів досліджень виявлено, що $64 \%$ дітей у віці до 6,5 років використовують мобільні пристрої; $25 \%$ з них роблять це щоденно; понад $26 \%$ дошкільників мають власні мобільні пристрої; $62 \%$ - досвід ігор із використанням смартфонів та планшетів [7, с. 152].

Зрозуміло, що є негативні наслідки такої діяльності. «Проведені Британськими вченими дослідження дітей у віці від 2 до 5 років довели існування прямого зв'язку між використанням дитиною аудіовізуальних медіа i погіршенням комунікативних здібностей. Однобічність контакту з телевізором (комп'ютером, планшетом), коли він «розмовляє» 3 малюком, не зупиняючись і не відповідаючи на запитання, призводить до того, що дитині стає важко спідкуватися 3 однолітками й доросдими, вона пізніше починає говорити. Однією з причин цієї проблеми є превалювання у структурі спілкування з дорослими «німого ефіру» (батьки разом із дітьми сидять біля екрана телевізора або одна із сторін біля комп'ютера) чи спілкування лише за потребами: «Дай», «Відійди», «Не чіпай», «Так», «Ні» тощо» [3, с. 144].

Також є дослідження, під час проведення яких з'ясовано, що навіть двогодинна гра дошкільника на планшеті спричинює значну недорозвиненість та неорганізованість білої речовини головного мозку в тих ділянках, які забезпечують навчальну діяльність [9].

Такі результати спонукають до виховання медіаграмотного молодого покодіння. Проте діти не завжди позитивно сприймають теми щодо дотримання норм безпечного використання новітніх пристроїв, як і низку інших тем, наприклад про непорушність авторського права під час виконання домашніх завдань у школі.

Проаналізувавши напрацювання Ю. Семеняко і здійснивши власні пошуки, ми дійшли висновку, що для формування мотивації до медіаосвіти необхідно врахувати особливості дошкільного та молодшого шкільного віку і забезпечити, щоб форми й методи освітнього процесу були цікавими, корисними та привабливими (емоційно забарвленими, видовищними, радісними). У дітей найбільше позитивних емоцій викдикають казки, ігри, святкові дійства. 3 цією метою нами створено новий медіапродукт - медіаосвітню казку [1, с. 85-100].

Аналіз змісту початкової освіти (типових програм для початкової школи) засвідчуе, що досягнення окремих програмних результатів може викликати труднощі, 030380 
наприклад знання класифікацій медіа. Відповідно до типових освітніх програм на уроках із літературного читання (змістова лінія «Досліджуємо і взаємодіємо 3 медіапродукцією») третьокласники пояснюють значення поняття медіа; розрізняють види медіа за джерелами і способами одержання інформації; аналізують медіатексти за критеріями, а також факти і судження про них; формулюють висновки за прочитаним, побаченим; дізнаються правила безпечної поведінки в інтернеті; створюють (за вибором) медіапродукт і обгрунтовують свій вибір; пояснюють роль ілюстрації як джерела розуміння тексту [4, с. 21]. Водночас пояснити, що означає слово «медіа», дитині може й раніше, ніж у третьому класі.

Це можна зробити в закладі дошкільної освіти під час читання медіаосвітньої казки. Діти дуже швидко запам'ятовують слова, що пов'язані 3 новітніми пристроями. Для трирічної дитини не становить труднощів повторити слово «павербанк» і пояснити, для чого він використовується. У медіаосвітній казці герої-звірята не лише розмірковують, що таке медіа, а й прагнуть, наприклад, до філантропічної діяльності: кому треба подарувати придбане з максимадьною користю. Отже, відбувається зв'язок пізнання медіапростору з моральним вихованням. На реалізацію цих самих цілей спрямовані авторські казки, у яких звірятко знехтувало авторським правом і привласнило собі чужу роботу [1, с. 99].

Казки написані 3 урахуванням вікових особливостей дітей і 3 дотриманням принципу наступності на теми визначення понять, пошуку інформації, диференціації правди й неправди в медіа, дотримання авторського права, економічних, праксеологічних аспектів медіа, їхнього безпечного використання. Медіаосвітні казки необхідно читати 3 дорослими: вихователями, вчителями, батьками, - щоб потім спільно аналізувати наслідки дій казкових звірят.

Медіаосвітня казка відповідає зразу трьом вимогам щодо формування мотивації до медіаосвітньої діяльності: щоб дітям було цікаво, щоб інформація була корисною і викликала позитивні емоціі.

Але це не єдині форми роботи. Читання медіаосвітніх казок варто поєднувати 3 переглядом вистав, проведенням бесід, дидактичними іграми, квестами, виконанням і демонстрацією проєктів тощо - усе це відображено в таблиці 1. Зрозуміло, що поділ форм і методів роботи на ті, що е цікавими, видовищними та корисними, відносний. Проте очевидно, що відбувається також домінування ефекту корисності, або позитивних емоцій (радісності).

Форми й методи формування мотивації дітей (дошкільного та молодшого шкільного віку у контексті наступності) до медіаосвіти через забезпечення цікавості, радісності й корисності представлені в таблиці 1.

Таблиия 1

\section{Форми й методи формування мотивації до медіаосвіти}

\begin{tabular}{|c|c|c|}
\hline $\begin{array}{l}\text { Форми й методи } \\
\text { роботи } 3 \text { дітьми } \\
\text { (цікавість) }\end{array}$ & $\begin{array}{l}\text { Форми й методи } \\
\text { роботи } 3 \text { дітьми } \\
\text { (радісність, } \\
\text { видовищність) }\end{array}$ & $\begin{array}{l}\text { Форми й методи роботи з дітьми } \\
\text { (корисність медіаосвіти) }\end{array}$ \\
\hline 1 & 2 & 3 \\
\hline \multicolumn{3}{|c|}{ Дошкільний вік } \\
\hline $\begin{array}{l}\text { Прослуховування } \\
\text { медіаосвітніх казок, } \\
\text { ігрова діяльність. }\end{array}$ & $\begin{array}{l}\text { Перегляд вистав } \\
\text { «Тітонько Сово, Ти знаєш, } \\
\text { що таке медіа?», забави. }\end{array}$ & $\begin{array}{l}\text { Медіаосвітні заняття, бесіди, розповіді } \\
\text { про шкоду від неконтродьованого } \\
\text { використання гаджетів, дидактичні ігри } \\
\text { щодо значення навчання про медіа: } \\
\text { виконання добрих справ, проведення } \\
\text { відьного часу, отримання потрібної } \\
\text { інформації, спілкування й презентація } \\
\text { себе. }\end{array}$ \\
\hline
\end{tabular}

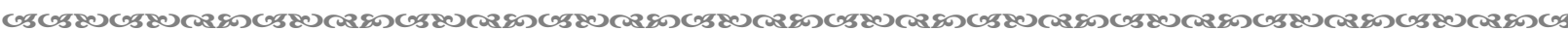


Продовження табл. 1

\begin{tabular}{|c|c|c|}
\hline 1 & 2 & 3 \\
\hline \multicolumn{3}{|c|}{$\begin{array}{c}\text { Мододший шкільний вік } \\
\text { (адаптаційно-ігровий етап початкової шкоди) }\end{array}$} \\
\hline $\begin{array}{lr}\text { Читання } & \text { медіаосвітніх } \\
\text { казок, } & \text { перегляд } \\
\text { телепередач та читання } \\
\text { дитячої преси; робота } 3 \\
\text { підручником. }\end{array}$ & $\begin{array}{l}\text { Інсценізація } \\
\text { медіаосвітньої казки про } \\
\text { користь медіа «Тітонько } \\
\text { Сово, розкажи про } \\
\text { користь медіа». }\end{array}$ & $\begin{array}{l}\text { Медіаосвітні заняття, бесіди, розповіді, } \\
\text { проєкти про значення навчання про } \\
\text { медіа, через медіа, для медіа: } \\
\text { отримання інформації, виконання } \\
\text { завдань із шкільних предметі; } \\
\text { орієнтація на успіх, рекламу власних } \\
\text { досягнень; робота з підручником. }\end{array}$ \\
\hline \multicolumn{3}{|c|}{$\begin{array}{c}\text { Молодший шкільний вік } \\
\text { (основний етап початкової школи) }\end{array}$} \\
\hline $\begin{array}{l}\text { Читання й складання } \\
\text { казок, } \\
\text { телепередач та дитячої } \\
\text { преси; квести; робота } 3 \\
\text { підручником. }\end{array}$ & $\begin{array}{lr}\text { Написання сценарію для } \\
\text { інсценізації } & \text { казки } \\
\text { «Тітонька Сова } \text { про } \\
\text { традиційні й новітні } \\
\text { медіа», участь у ній; } \\
\text { медіаосвітнє свято «Медіа } \\
\text { єднає друзів». }\end{array}$ & $\begin{array}{l}\text { Медіаосвітні заняття, бесіди, розповіді, } \\
\text { проєкти, тренінги про значення } \\
\text { навчання про медіа, через медіа, для } \\
\text { медіа: досягнення життєвих цілей, } \\
\text { планів, успіху в школі; збереженя } \\
\text { здоров'я, організація відпочинку, } \\
\text { ефективна комунікація, попередженяя } \\
\text { маніпудяцій. }\end{array}$ \\
\hline
\end{tabular}

Розроблені форми й методи формування мотивації до медіаосвіти є джерелом для вияву творчості педагогічних колективів початкових шкіл, батьків та дітей. За зразком медіаосвітніх казок можна створювати як нові казки відповідно до інновацій у медіаосвіті, так і неведикі сценарії вистав на теми: «Тітонько Сово, Ти знаєш, що таке медіа?», «Тітонька Сова про традиційні й новітні медіа»; свята «Медіа єднає друзів» тощо. Таким чином у спільній творчій діяльності створюватимуться нові медіапродукти.

Висновки. У закладах дошкільної та початкової освіти відбуваються позитивні зміни щодо впровадження медіаосвіти: ці проблеми відображені в типових освітніх програмах для початкових шкіл, реалізовуються цікаві методичні розробки на теми медіаосвіти для роботи 3 дошкільнятами. Водночас розробляються нові напрями медіаосвіти, а медіаграмотність сприймають як тканину з різнокольорових волокон різної товщини. Багатогранність і актуальність проблем медіаосвіти зумовдюе нові перспективні напрями ऑiі здійснення, доцільність розробки інноваційних шляхів формування мотивації до цього виду діядьності. Корисність, привабливість (видовищність, радісність), цікавість і є тими мотивами, що спонукають до занять у сфері медіаосвіти. Цим вимогам відповідае новий медіапродукт - медіаосвітня казка для дошкільників і мододших школярів у контексті наступності. Перспективний напрям роботи - написання у співпраці з батьками й педагогами сценаріїв мінівистав із участю популярного героя мультиплікаційних фільмів Тітоньки Сови.

Перспективи подальших досліджень полягають у розробці інноваційних медіаосвітніх продуктів та напрямів медіаосвіти для дітей дошкільного та мододшого шкільного віку в контексті наступності.

\section{Список використаних джерел:}

1. Кузьма I. І. Медіаосвіта в закдадах дошкільної та початкової освіти : методичні рекомендації. Тернопіль : Вектор, 2020. 126 с.

2. Семеняко Ю. Б. Виховання у дітей старшого дошкільного віку основ культури використання медіапродукції у закладах дошкільної освіти : дис. ... канд. пед. наук : 13.00 .08 / Інститут проблем виховання Національної академії педагогічних наук України. Київ, 2019.

3. Семеняко Ю. Культура медіа-споживання в сім'ї: сучасний стан дослідження проблеми. Молодь $i$ ринок. $2016 . \quad$ № 11-12 (142-143). $\quad$ С. $144 . \quad$ URL: file:///C:/Users/admin/Downloads/Mir 2016 11-12 32.pdf

4. Типова освітня програма, розроблена під керівництвом Савченко О. Я. 3-4 клас. URL : https://mon.gov.ua/storage/app/media/zagalna\%20serednya/programy-1-4-klas/2019/11/3-4-dodatki.pdf 
5. Шейбе С., Рогоу Ф. Медіаграмотність : підручник для вчителів / перекл. з англ. С. Дьома ; за загал. ред. В. Ф. Іванова, О.В.Волошенюк. Київ: Центр Вільної Преси, Академія Української Преси, 2017.

6. Янкович О.І.Моральне виховання учнів молодшого шкільного віку в процесі реалізації медіаосвіти. Педагогічний альманах: збірник наукових праць / редкол. В.В. Кузьменко (голова) та ін. Херсон : КВНЗ «Херсонська академія неперервної освіти», 2017. Випуск 33. С. 18-24.

7. Brzyszcz E. Kształcenie kompetencji medialnych u dzieci $w$ wieku przedszkolnym. Edukacja medialna $\mathrm{w}$ niepublicznym naukowym przedszkolu integracyjnym mini College w Kelcach. Państwo $\quad i \quad$ Społeczeństwo. $2017 . \quad$ № 3 (XVII). https://kometa.edu.pl/uploads/publication/487/1fed AAA pis 2017310 Brzvszcz.pdf?v2.8

8. Juszczyk-Rygałło J. Wczesnoszkolna edukacja medialna jako wprowadzenie do edukacji całożyciowej. Prace Naukowe Academii im. Jana Długosza w Częstochowie. Pedagogika. 2015. XXIV. S. 89-99. URL : https://docplayer.pl/23785662-Wczesnoszkolna-edukacja-medialna-jako-wprowadzenie-doedukacji-calozyciowej.html

9. LaMotte S. This is your child's brain on books: Scans show benefit of reading vs. screen time. 2020. URL : https://edition.cnn.com/2020/01/16/health/child-brain-reading-books-wellness/index.html

10. Ogonowska A. Edukacja medialna: ziemia wciąż nieznana?... Kultura - społeczeństwo - edukacja. 2012. Nr 1 S. 173-191. URL : https://core.ac.uk/download/pdf/154440572.pdf

11. Tereshchuk H. V., Kuzma I. I., Yankovych O. I., Falfushynska H. I. The formation of a successful personality of a pupil in Ukrainian primary school during media education implementation. Cloud Technologies in Education. Proceedings of the 6th Workshop CTE 2018 (Kryvyi Rih, Ukraine, December 21, 2018) / Eds. Kiv, A. E., Soloviev, V. N. CEUR-WS.org, online. P. 145-158. URL: http://ceur-ws.org/Vol-2433/paper08.pdf

12. Yankovych O. I., Chaika V. M., Ivanova T. V., Binytska K. M., Kuzma I. I., Pysarchuk O. T., Falfushynska H. I. Technology of forming medialiteracy of children of the senior pre-school age of Ukraine. Cloud Technologies in Education. Proceedings of the 6th Workshop CTE 2018 (Kryvyi Rih, Ukraine, December 21, 2018) / Eds. Kiv, A. E., Soloviev, V. N. CEUR-WS.org, online. P. 126-144. URL : http://ceur-ws.org/Vol-2433/paper07.pdf

\section{References:}

1. Kuzma, I. I. (2020). Mediaosvita $v$ zakladakh doshkilnoi ta pochatkovoi osvity: metodychni rekomendatsii [Media education at preschool and primary educational institutions: methodical recommendations]. Ternopil: Vektor [in Ukrainian].

2. Semeniako, Yu. B. (2019). Vykhovannia u ditei starshoho doshkilnoho viku osnov kultury vykorystannia mediaproduktsii $u$ zakladakh doshkilnoi osvity [The upbringing in preschool children of the bases of the culture of using media production in pre-school establishments]. (Candidate's thesis). Institute of Education Problems of the National Academy of Pedagogical Sciences of Ukraine. Kyiv [in Ukrainian].

3. Semeniako, Yu. B. (2016). Kultura media-spozhyvannia v simi: suchasnyi stan doslidzhennia problemy [The culture of using media in the family: the current state of research]. Molod i rynok, 11-12 (142-143), 144. Retrieved from file:///C:/Users/admin/Downloads/Mir 2016 11-12 32.pdf [in Ukrainian].

4. Typova osvitnia prohrama, rozroblena pid kerivnytstvom Savchenko O. Ya. 3-4klas [A typical educational program developed under the guidance of Savchenko O. Ya. 3-4 grades]. Retrieved from $\quad$ https://mon.gov.ua/storage/app/media/zagalna\%20serednya/programy-1-4-klas/2019/11/3-4dodatki.pdf [in Ukrainian].

5. Sheibe, S. \& Rogou, F. (2017). Mediahramotnist: Pidruchnyk dlia vchyteliv [Media literacy: a textbook for teachers]. (S. Dyoma, Trans.). Kyiv: Tsentr Vilnoi Presy, Akademiia Ukrainskoi Presy [in Ukrainian].

6. Yankovych, O. I. (2017). Moralne vykhovannia uchniv molodshoho shkilnoho viku v protsesi realizatsii mediaosvity [Moral education of primary school pupils in the process of media education]. Pedahohichnyi almanakh: zbirnyk naukovykh prats, 33, 18-24 [in Ukrainian].

7. Brzyszcz, E. (2017). Kształcenie kompetencji medialnych u dzieci $w$ wieku przedszkolnym. Edukacja medialna $\mathrm{w}$ niepublicznym naukowym przedszkolu integracyjnym mini College w Kelcach [Education of media competence in children of preschool age: media education in NonPublic Scientific Integration Nursery "Mini College" in Kielce]. State and Society, 3 (XVII). Retrieved 
from https://kometa.edu.pl/uploads/publication/487/1fed_AAA_pis_2017_3_10_Brzyszcz.pdf?v2.8 [in Polish].

8. Juszczyk-Rygałło, J. (2015). Wczesnoszkolna edukacja medialna jako wprowadzenie do edukacji całożyciowej [Early school media education as an introduction to life-long learning]. Scientific works of the Academy of Jan Dtugosz in Czestochowa. Pedagogy, XXIV, 89-99. Retrieved from https://docplayer.pl/23785662-Wczesnoszkolna-edukacja-medialna-jako-wprowadzenie-doedukacji-calozyciowej.html [in Polish].

9. LaMotte, S. (2020). This is your child's brain on books: Scans show benefit of reading vs. screen time. Retrieved from https://edition.cnn.com/2020/01/16/health/child-brain-reading-bookswellness/index.html [in English].

10. Ogonowska, A. (2012). Edukacja medialna: ziemia wciąż nieznana? [Media Education: Still a Terra Incognita?]. Culture - Society - Education, 1, 173-191. Retrieved from https://core.ac.uk/download/pdf/154440572.pdf [in Polish].

11. Tereshchuk, H. V., Kuzma, I. I., Yankovych, O. I. \& Falfushynska, H. I. (2018). The formation of a successful personality of a pupil in Ukrainian primary school during media education implementation, Cloud Technologies in Education, Proceedings of the 6th Workshop CTE 2018. Kryvyi Rih. Retrieved from http://ceur-ws.org/Vol-2433/paper08.pdf [in English].

12. Yankovych, O. I., Chaika, V. M., Ivanova, T. V., Binytska, K. M., Kuzma, I. I., Pysarchuk, O. T. \& Falfushynska, H. I. (2018). Technology of forming medialiteracy of children of the senior preschool age of Ukraine, Cloud Technologies in Education, Proceedings of the 6th Workshop CTE 2018. Kryvyi Rih. Retrieved from http://ceur-ws.org/Vol-2433/paper07.pdf [in English].

Kuzma I. I., orcid.org/0000-0002-1219-8216

\section{FORMATION OF MOTIVATION FOR MEDIA EDUCATION IN CHILDREN OF SENIOR PRESCHOOL AND PRIMARY SCHOOL AGE}

The article substantiates the forms and methods of forming motivation for media education in preschool and primary school age children in the context of continuity. There has been offered the use of a new media product - a media education tale on the topics of defining the terms, searching for information, differentiation of truth and falsehood in the media, compliance with copyright, economic, praxeological aspects of the media, their safe use.

It has been noted that media education is an urgent interdisciplinary problem, there are many areas of media education. Their implementation requires new approaches, especially the formation of motivation in preschool and primary school age children in the context of continuity. Usefulness, attractiveness (entertainment, joy), curiosity have been defined as motives that motivate for lessons in the field of media education.

Emphasis has been placed on the negative impact of excessive use of new media. It has been noted that in primary schools typical educational programs are aimed at the formation of media literacy of pupils. At the same time, this work needs to be strengthened in preschool educational institutions.

There has been revealed the need to create motivation for media education and implement it in cooperation with teachers, parents, children (conversations, stories, games, exercises, projects, trainings on the importance of learning about the media, through the media, for the media); by combining media education with different areas of education: moral, aesthetic, labor, etc. - which is reflected in media education tales. Promising forms of work have been identified. They are the following: writing scripts for mini-plays with the participation of the popular cartoon character Aunt Owl; media educational holiday "Media unites friends", etc.

Emphasis has been placed on the fact that the developed forms and methods of forming motivation for media education are the source for expressing the creativity of pedagogical teams of primary schools, parents and children, further scientific research.

Key words: preschool educational institution, primary educational institution, media, media education, media literacy, motivation for media education, media education tale, forms, methods of media education. 